\title{
Anthropogenic Disturbances and the Natural Vegetation Regeneration: A Case Study of a Forest Fragment Located in a Cuesta Relief Area, State of São Paulo, Brazil
}

\author{
Luiz Alberto Blanco Jorge*, Vanessa Rodrigues Pereira \\ Department of Forest Science-FCA, UNESP, Botucatu, Brazil \\ Email: blanco@fca.unesp.br
}

Received 11 June 2015; accepted 21 August 2015; published 25 August 2015

Copyright (C) 2015 by authors and Scientific Research Publishing Inc.

This work is licensed under the Creative Commons Attribution International License (CC BY).

http://creativecommons.org/licenses/by/4.0/

c) (i)

\section{Abstract}

The present study has been conducted in one of the five natural vegetation fragments at the Experimental Farm Edgardia, in Botucatu, São Paulo State, Brazil. In the past the forest fragment suffered disturbances due to the selective exploitation of tree species and the use of part of the surface as pasture. The objectives of this research were to evaluate the structure and the dynamics of natural vegetation. Three phytosociological surveys $(2006,2010$ and 2014) were carried out in a sampled area of one hectare. The most abundant species were mapped in 2014, in a sampling unit with two hectares. Individuals of 37 families and 110 species have been recorded. The oscillation of the basal area observed through the forest inventories was due to the instability caused by disturbances. Only two out of the seven most abundant species mapped showed exponential diameter distribution. The unimodal distributions shown by the other five species have suggested that the vegetation has been occupying the most open spaces through regeneration in cycles. There was direct association between the spatial distribution and the dispersion syndrome for five out of the seven most abundant species. Three species have zoochoric dispersion, showing that wild animals populations have accomplished their function in the dispersion of seeds/fruit. The spatial distributions of four out of the seven most abundant species have provided evidence of how the regeneration of natural vegetation is being processed in this area.

\section{Keywords}

Secondary Succession, Diameter Distribution, Spatial Statistics, Vegetation Structure

\footnotetext{
${ }^{*}$ Corresponding author.
} 


\section{Introduction}

The landscapes inland in the State of São Paulo, Brazil, have heavily been modified by man, which led to the decline and fragmentation of the natural vegetation, reflecting directly on the soil conservation and the water resources, as well as the diversity of flora and fauna. In this context, the Experimental Farm Edgardia, managed by the UNESP, presents five fragments of natural vegetation, comprising an area of 740 hectares, conforming great importance for Botucatu municipality and Capivara River Basin, where the experimental unit is set.

This present paper refers to one of the forest fragments at Experimental Farm Edgardia, located on sandy soil with low fertility in the area of peripheral depression in the cuesta in Botucatu. The forest fragment has suffered disturbances in the past, which are due to: 1) the selective exploitation of the economically important tree species and 2) the use of part of the surface as pasture.

According to Elliott et al. (2013), a tropical forest is characterized by a mosaic of gaps in different sizes, regenerating patches and old growth, with species composition varying according to microhabitat, the disturbance history, limitation of seed dispersion and chance events. All these factors contribute to the high diversity of species. Due to these occurring disturbances there might be a reversal to a temporary initial ecosystem or seral stage in the succession sequence. The nature of the seral stage depends on the severity of the disturbance. A major disturbance can completely destroy the community of plants and the soil. Less severe disturbances, such as exploitation, cultivation and fire, transform the forests into grass or shrub areas. When disturbances cease, sequential changes in species composition occur due to interactions among plants, animals and the surrounding environment. Grass and shrubs initiate secondary succession, where the shrubs shade out herbs. Pioneer trees that need light shade the shrubs and much later, these become shaded by tolerant trees. Thus, the forest becomes progressively denser, structurally more complex and richer in species, as the succession drives to the climax conditions. Even under the best conditions, this process may take 80 - 150 years to be complete.

Local anthropogenic effects on tropical forests include land-cover change, invasive species and timber extraction (Wright, 2005). Some studies have assessed the impact of different degrees of disturbance on the species composition, structure and dynamics (Sagar et al., 2003; Hitimana et al., 2009). Secondary forests resulted from these disturbances have rapid rates of aboveground production, especially during the early stages of succession. Consequently, they have the potential to assimilate and store relatively large fractions of carbon and nutrients that are lost during deforestation and land use phases (Hughes et al., 1999).

One tried to understand the process of the vegetation regeneration in this study area. This understanding is important for the conservation of this natural resource, but it is also important for offering subsidies during the pre-selection of species to be tested for the purpose of restoration. The current research aimed to answer the following question: how has the natural vegetation behaved up until the present moment, before two anthropogenic disturbances checked on site? For this purpose, the specific objectives of this research were: 1) to evaluate the structure and the dynamics of the natural vegetation; 2) to analyze the diameter distribution of each tree species which was more abundant among the ten with the highest importance value in the area; 3 ) to check the spatial distribution patterns and the associations among tree species which were more abundant in the forest fragment.

\section{Material and Methods}

\subsection{Study Area}

The studied forest fragment lies on Experimental Farm Edgardia (1200 ha) (Figure 1), in Botucatu, State of São Paulo, and between the geographical coordinates $22^{\circ} 47^{\prime} 30^{\prime \prime}$ and $22^{\circ} 50^{\prime}$ latitude $\mathrm{S}$ and $48^{\circ} 26^{\prime} 15^{\prime \prime}$ and $48^{\circ} 22^{\prime} 30^{\prime \prime}$ longitude W. On this site two geomorphic units are observed: cuesta front, a basaltic escarpment with their originated soils and the peripheral depression, comprising the presence of sandstones and alluvial sediments, mainly at east, covering the wetlands of the Capivara River Basin, 250 meters lower in relation to the basaltic Cuesta (Carvalho et al., 1991).

The climate in this region has two distinct seasons: a rainy and warm season (from September to March) and a dry and cool one (from April to August). The average annual rainfall is $1428.4 \mathrm{~mm}$. The average annual temperature is $20.3^{\circ} \mathrm{C}$, with monthly averages ranging from $17.1^{\circ} \mathrm{C}$ (July) to $23.1^{\circ} \mathrm{C}$ (February) (da Cunha \& Martins, 2009). The main uses of the land at Edgardia Farm are for extensive livestock grazing, crops and small areas for forest plantations. 


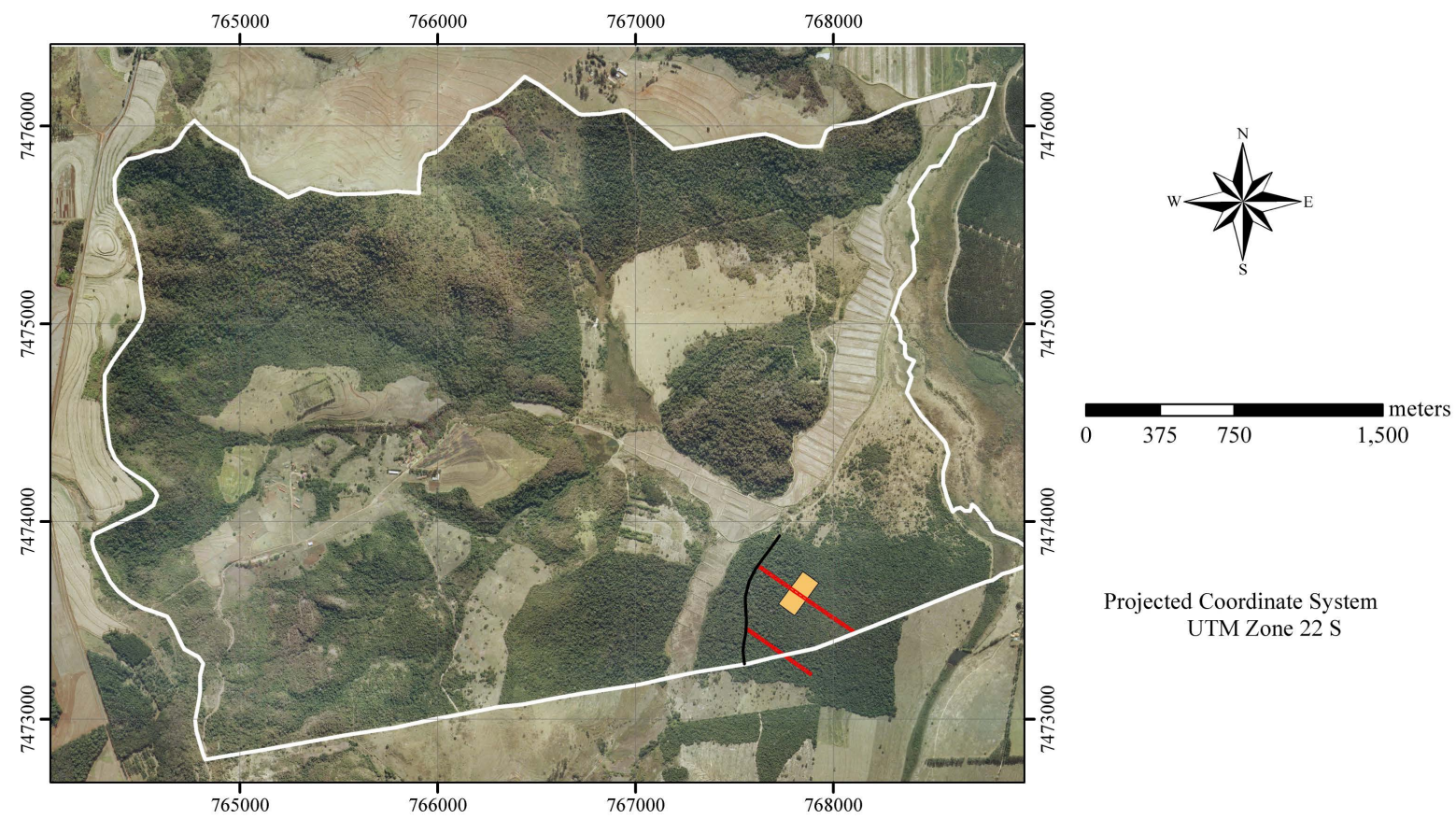

Figure 1. Position of the two transects of adjoining units (red) in relation to the sampling area for the mapping of the most abundant species (rectangle in orange), on aerial photography of 2005, which shows the limits of the Edgardia Experimental Farm (in white).

The natural vegetation (with 740 hectares and 61.67 percent of total farm area) partially sheds its leaves during the dry season. It is classified as semi-deciduous forest (IBGE, 2012). In the area it occurs forest fragments showing different levels of anthropogenic disturbance. They are also present in the remaining place of transition vegetation between forest and forested savanna, and riparian forests.

The inventoried forest fragment, where the vegetation is characterized as an ecotone between semidecidual seasonal forest and forested savanna, is situated in an area of predominantly Albic Arenosols, with low fertility. Most of the 111.29 hectares of the vegetation fragment are located on the Edgardia Farm, but a portion of the study area is located on a neighboring property.

This fragment has suffered disturbances generated in the past by: 1) selective exploitation of economically important tree species (area 1 in Figure 2), with the last intervention occurring between 1975 and 1980 (extraction of Astronium graveolens (Anacardiaceae), Copaifera langsdorffii (Fabaceae-Caesalpinioideae) and Hymenaea courbaril (Fabaceae-Caesalpinioideae) individuals); and 2) use of part of the area as pastureland (area 2 in Figure 2).

\subsection{Phytosociological Surveys}

The phytosociological surveys of the natural vegetation of the forest fragment, which were conducted in 2006, 2010 and 2014, involved an initial allocation of adjoining units of $10 \times 25 \mathrm{~m}$ strips transecting the variation gradient, characterizing a systematic single-stage sampling design. The distance between the two transects was 300 meters. A total of 40 permanent units were sampled (first transect units numbered from 1 to 24 and second transect units numbered from 25 to 40 (Figure 3)), covering an area of 1 hectare. The entry and exit points of the transects in the fragment, as well as the location of the units in the field, were georeferenced using GPS. All individual trees in the sampling units presenting a diameter at breast height $(\mathrm{DBH}) \geq 4.8 \mathrm{~cm}$ were inventoried. A collection of botanical material allowed for the identification of the species occurring in the area. Exsiccata of reproductive material were deposited in the herbarium of the Department of Forest Science of the Faculty of Agronomic Sciences of UNESP at Botucatu. The species found in the forest fragment were classified according to the APG III botanical classification system, checking the species list of flora in Brazil (Jardim Botânico do Rio de Janeiro, 2014). 


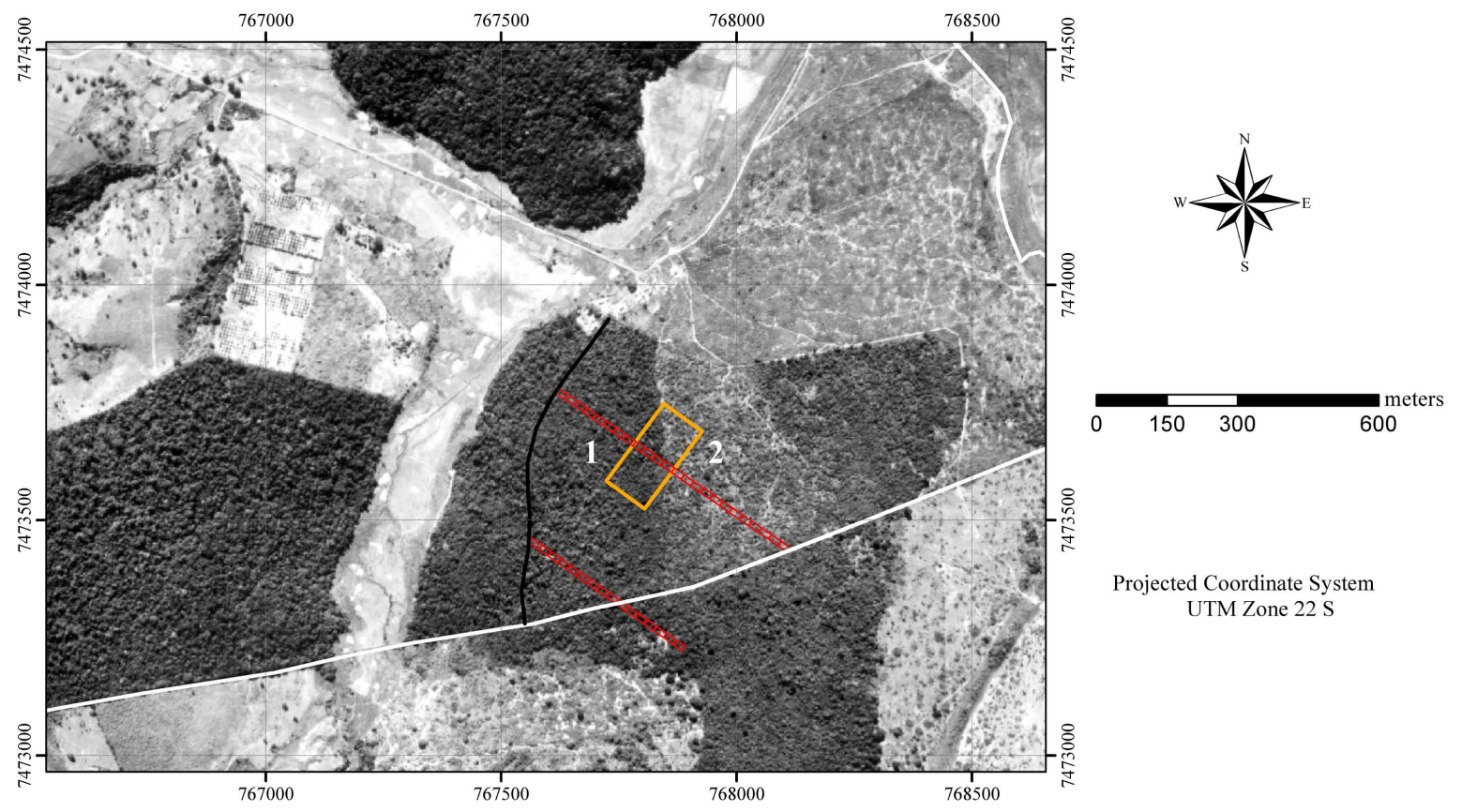

Figure 2. Position detail of the two transects of adjoining units (red) in relation to the sampling area for the mapping of the most abundant species (rectangle with orange lines), on aerial photography of 1962.

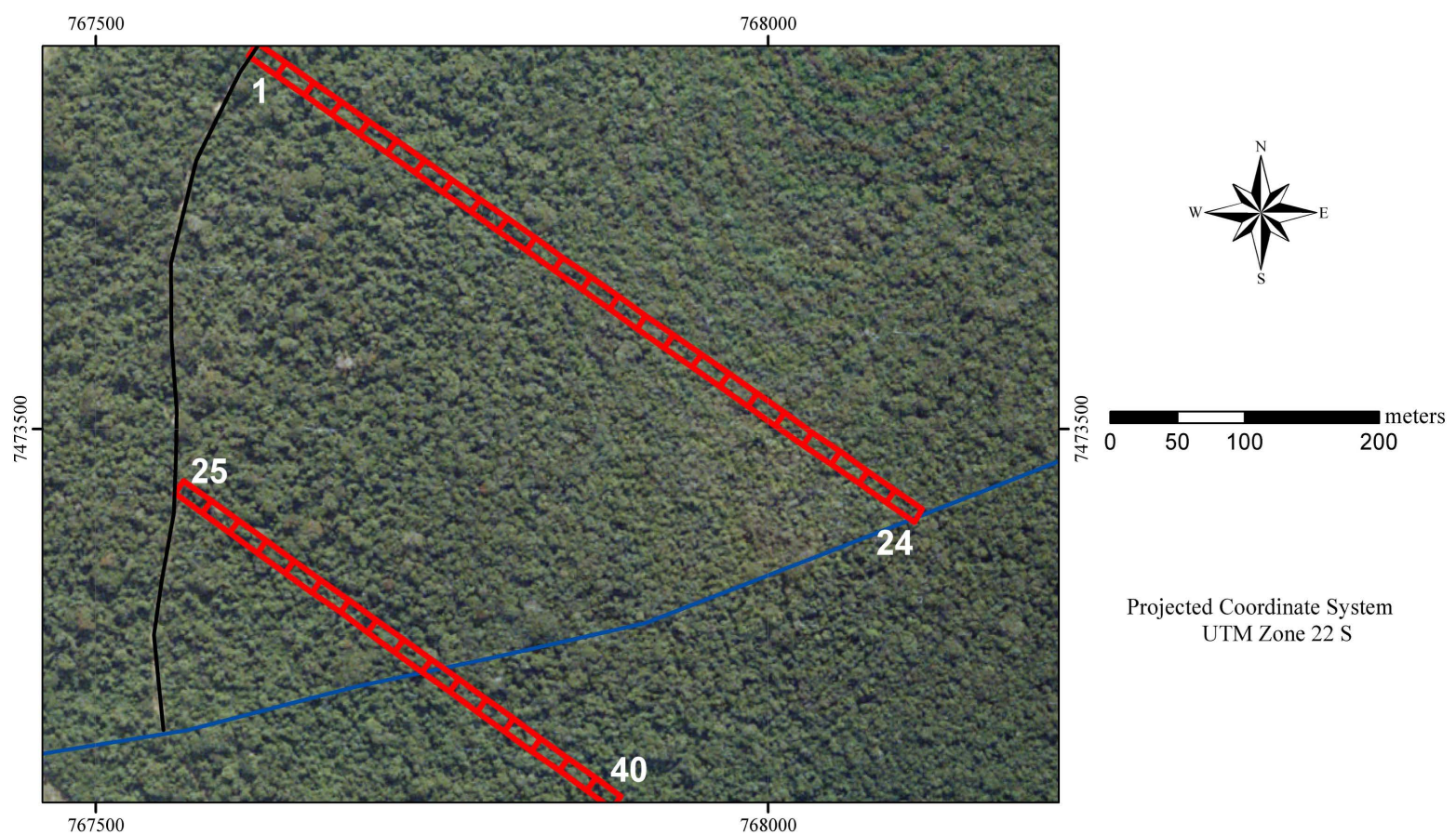

Figure 3. Position of the forty permanent units (red) sampled in the phytosociological surveys.

The quantitative parameters employed in the study of the horizontal structure of the vegetation were absolute density-AD (1), relative density-RD (2), absolute dominance-ADo (3), relative dominance-RDo (4), absolute frequency-AF (5) and relative frequency-RF (6), which were also expressed in the form of an importance value index-IVI (7) resulting from the sum of the relative values of these parameters (Müeller-Dombois \& Ellenberg, 1974). The parameters related to the horizontal structure of the sample of 1 hectare were calculated for 2006, 2010 
and 2014, after developing corresponding script in the environment of the software R (R Core Team, 2013).

$$
\begin{gathered}
A D_{i}=\frac{n_{i}}{A} \\
R D_{i}=\frac{A D_{i}}{\sum_{i=1}^{P} A D_{i}} \times 100 \\
A D o_{i}=\frac{G_{i}}{A} \\
R D o_{i}=\frac{A D o_{i}}{\sum_{i=1}^{P} A D o_{i}} \times 100 \\
A F_{i}=\frac{u_{i}}{u_{t}} \times 100 \\
R F_{i}=\frac{A F_{i}}{\sum_{i=1}^{P} A F_{i}} \times 100 \\
I V I_{i}=R D_{i}+R D o_{i}+R F_{i}
\end{gathered}
$$

where $n_{i}=$ number of sampled individuals for the ith species; $G_{i}=$ basal area for the $i$ th species; $u_{i}=$ number of sample units where the $i$ th species is present; $u_{t}=$ total number of sample units; $P=$ number of sampled species; $A=$ sampled area (in hectares);

\subsection{Mapping of the Most Abundant Species}

Individuals occurring in a sampled rectangular area of 2 hectares (Figure 1 and Figure 2) have been mapped for the analysis of the spatial distribution of the most abundant species in this forest fragment, based on the methodology described by Figueiredo and Cunha (2007) using GPS with high sensitivity antenna, allowing to capture the satellite signals even under the coverage of trees. The mapping included individuals with minimum DBH of $4.8 \mathrm{~cm}$.

The diameter distributions of the most abundant species among the ten with the highest importance value in this surveyed area have been made. The frequencies observed by diameter classes have been computed from the development of the corresponding script, which has been programmed within the software R environment. Trying to describe the behavior of the diameter distributions showing a $\mathrm{J}$ reverted pattern in a more detailed manner, three exponential models have been set (Table 1). The best adjustment possible has indicated whether the decrease in the number of trees related to a specific distribution has approached a uniform geometric progression-Type I, increasing geometric progression-Type II, or decreasing geometric progression-Type III (Loetsch et al., 1973).

Based on the linearized model (Table 1) linear equations have been used as functions of self-initiation for the adjustment of nonlinear equations within the statistical software R (Ritz and Streibig, 2008) as initial values of the coefficients a, b, respectively taken by $\mathrm{e}^{\mathrm{b} 0}, \mathrm{~b}_{1}$.

Four models (Table 2) have been applied in this present research when the observed frequencies of a given species showed a unimodal diameter distribution pattern. The linearized models have been adjusted. The best equation based on the coefficient of determination $\left(R^{2}\right)$ has been selected, as well as standard error of estimate (S.E.) and the coefficients significance. After having derived the antilogarithm of the chosen equation, the estimated distribution was described.

Among other statistics, the quality of the adjustment for equations used to describe the diameter distributions, both for those with a standard inverted $\mathrm{J}$, as well as for the unimodal, has been measured by the adjustment index-AI (22).

$$
\mathrm{AI}=100\left[1-\frac{\sum_{i=1}^{n}\left(y_{i}-\widehat{y_{i}}\right)^{2}}{\sum_{i=1}^{n}\left(y_{i}-\overline{y_{i}}\right)^{2}}\right]
$$


Table 1. Models adjusted for inverted J curve of diameter distribution.

\begin{tabular}{cccc}
\hline Type & Geometric progression & Exponential model & Linear model \\
\hline I & Uniform & $N_{i}=a \mathrm{e}^{b d_{i}} \quad(8)$ & $\ln N_{i}=b_{0}+b_{1} d_{i} \quad(11)$ \\
II & Increasing & $N_{i}=a \mathrm{e}^{b d_{i}^{2}} \quad(9)$ & $\ln N_{i}=b_{0}+b_{1} d_{i}^{2} \quad(12)$ \\
III & Decreasing & $N_{i}=a \mathrm{e}^{b d_{i}^{1 / 2}} \quad(10)$ & $\ln N_{i}=b_{0}+b_{1} d_{i}^{1 / 2}(13)$ \\
\hline
\end{tabular}

$N_{i}=$ number of individuals in class $i ; d_{i}=$ center of diameter class $i ; a, b=$ coefficients of exponential models; $b_{0}, b_{1}=$ coefficients of linear models.

Table 2. Models adjusted for unimodal diameter distribution.

\begin{tabular}{|c|c|}
\hline Model & Linear model \\
\hline$N_{i}=a d_{i}^{b} \mathrm{e}^{c d_{i}}$ & $\ln N_{i}=b_{0}+b_{1} \ln d_{i}+b_{2} d_{i}$ \\
\hline$N_{i}=a d_{i}^{b} \mathrm{e}^{c d_{i}^{2}}$ & $\ln N_{i}=b_{0}+b_{1} \ln d_{i}+b_{2} d_{i}^{2}$ \\
\hline$N_{i}=a d_{i}^{b} \mathrm{e}^{c d_{i}^{1 / 2}}$ & $\ln N_{i}=b_{0}+b_{1} \ln d_{i}+b_{2} d_{i}^{1 / 2}$ \\
\hline$N_{i}=a d_{i}^{b} \mathrm{e}^{c d \gamma}$ & $\ln N_{i}=b_{0}+b_{1} \ln d_{i}+b_{2} d_{i}^{\gamma}$ \\
\hline
\end{tabular}

$N_{i}=$ number of individuals in class $i ; d_{i}=$ center of diameter class $i ; a, b, c=$ coefficients of nonlinear models; $b_{0}, b_{1}, b_{2}=$ coefficients of linear models; $\gamma=$ power.

where $y_{i}=$ observed absolute frequency in diameter class $i ; \widehat{y_{i}}=$ expected absolute frequency in diameter class $i ; \overline{y_{i}}=$ average frequency of $n$ classes.

The point maps containing the position of each evaluated individual species for the spatial distribution have been prepared within the ArcInfo v.10 software environment based on the GPS files. In a second moment, the data were transferred to the software R environment, using the package "spatstat" (Baddeley, 2010).

Ripley K function computes the distances among all the trees on a map (Cruz-Rot, 2006). In a simplified way, the procedure involves generating a rradius circle centered on each tree. The number of neighbors within each circle is counted. By varying the $\mathrm{r}$ radius, it is possible to detect spatial patterns at different scales. In order to determine the distribution pattern of individuals of the most abundant species the $L$ function has been applied in accordance with Cruz-Rot (2006) and Dalmaso et al. (2012). The L function is transformed from the univariated $\mathrm{K}$ function $\left(\mathrm{L}(\mathrm{r})=(\mathrm{K}(\mathrm{r}) / \pi)^{1 / 2}\right)$. Significance tests for spatial measurements are usually built using the Monte Carlo simulations (Diggle, 2003). For the univariated function, the null hypothesis is from the complete spatial randomness (test if $\mathrm{L}(\mathrm{r})-\mathrm{r}=0$ to each $\mathrm{r}$ distance). The hypothesis has been tested in "spatstat" in 500 Monte Carlo simulations as $\alpha=0.01$. Confidence envelopes have been created. Thus, for the observed values inside these envelopes, random spatial patterns have been considered. For positive values outside these confidence envelopes, null hypothesis has been rejected and the spatial pattern as aggregate has been considered.

Tests of interaction between species have been carried out with the use of $K_{12}$ bivariate function and the $L_{12}$ corresponding function (Cruz-Rot, 2006). The observed values for $\mathrm{L}_{12}$ have been compared to the theoretical values for a null value of the independence hypothesis corresponding to the absence of interaction between the two kinds of points. The null model (spatial independence hypothesis) has been generated with 500 simulations for $\alpha=0.01$, using the package "spatstat".

\section{Results and Discussion}

\subsection{Natural Vegetation Behavior}

The phytosociological surveys involved individuals from 37 families and from 110 species. The diameter distribution of the forest community based on the inventory of 2014 has been characterized by a typical pattern in inverted J (Figure 4). The basal area $\left(\mathrm{m}^{2} / \mathrm{ha}\right.$ ) of measured individuals in the sampled area of one hectare showed the value of 16.6419 in 2006, increasing to 18.5184 in 2010, slightly decreasing to 18.3363 in 2014 . This oscillation in the basal area is due to the instability caused by disturbances in the fragment, which is in the process of regeneration. Changes in the distribution of the basal area of the 40 sampled units also occurred between 2006 


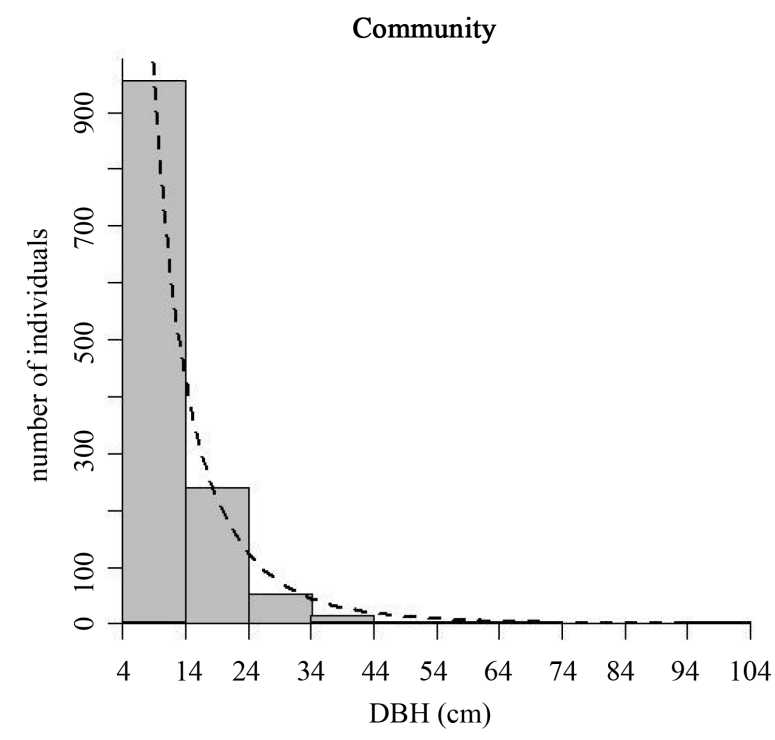

Figure 4. Diametric distribution of forest community based on the 2014 inventory.

and 2014 (Figure 5).

Regarding phytosociological surveys from 2006, 2010 and 2014, eight species have remained among the ten with the highest importance value-IVI (Figure 6). Three other species have been in and out of the list of the ten highest IVIs within eight years of observation but these were at the minimum in the eleventh position.

\subsection{Diametric Structure of the Most Abundant Species}

Analyzing the diameters distributions (Table 3 and Table 4, Figure 7) of the seven most abundant species in the forest fragment which remained on the list among the ten with the highest importance value from 2006 to 2014, it was found that for two of them Trichilia pallida (Meliaceae) and Metrodorea nigra (Rutaceae) a standard inverted J had occurred, an indication that the regeneration has processed continuously. Five further species (Croton floribundus (Euphorbiaceae), Mabea fistulifera (Euphorbiaceae), Ocotea velutina (Lauraceae), Astronium graveolens (Anacardiaceae) and Copaifera langsdorffii (Fabaceae-Caesalpinioideae)) have shown a unimodal distribution pattern, characteristic of regeneration in cycles.

The equations used in the description of distributions in inverted $\mathrm{J}$ for Trichilia pallida and Metrodorea nigra, have been adjusted from the model (9) and have been selected based on the coefficients significance level, on the standard error of the estimate values (S.E.) and on the adjustment index-AI\% (Table 3). The selection of equations related to model (9) shows that the decrease of individuals within the classes took place in increasing geometrical progression.

The equations used in the description of the unimodal distributions for Croton floribundus, Mabea fistulifera, Ocotea velutina, Astronium graveolens and copaifera langsdorffii have been adjusted, respectively, from models (19), (18), (21), (21) and (18), selected based on the coefficients significance level, on the standard error of the estimate values (S.E.), on the adjusted determination coefficient $\left(R_{\text {adjusted }}^{2}\right)$ and on the adjustment index-AI\% (Table 4).

\subsection{Spatial Arrangement of the Most Abundant Species}

The mapping of trees has allowed checking the distribution of individuals among the seven species (Figure 8) within the surveyed area of two hectares in 2014 in the remaining natural vegetation. It was possible to determine the spatial distribution pattern of the species (Figure 9). Croton floribundus, Trichilia pallida, Mabea fistulifera, Astronium graveolens and Metrodorea nigra have shown an aggregated distribution of the individuals based on the fact that, for these five species, the line describing the $L$ function has exceeded the expected theoretical value, this is, the confidence envelope (gray area). As for Copaifera langsdorffii the empirical function (estimated L) 


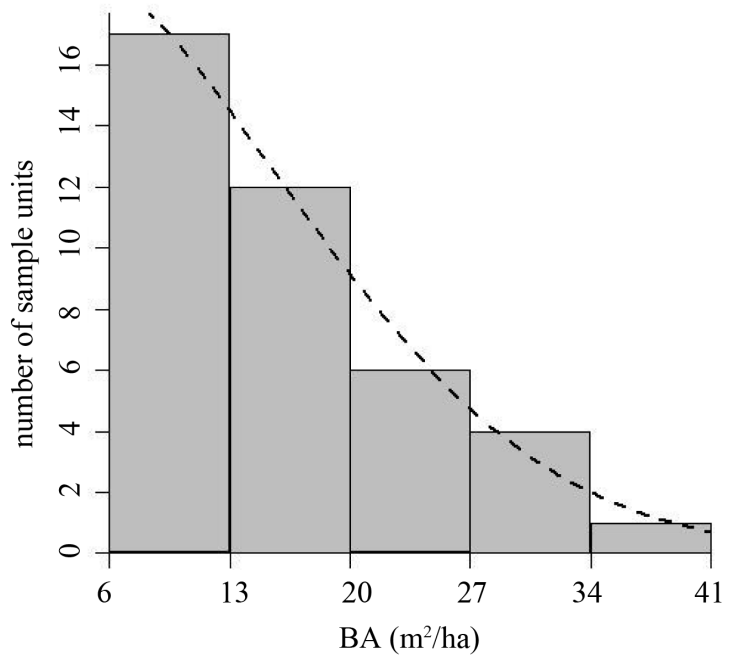

(a)

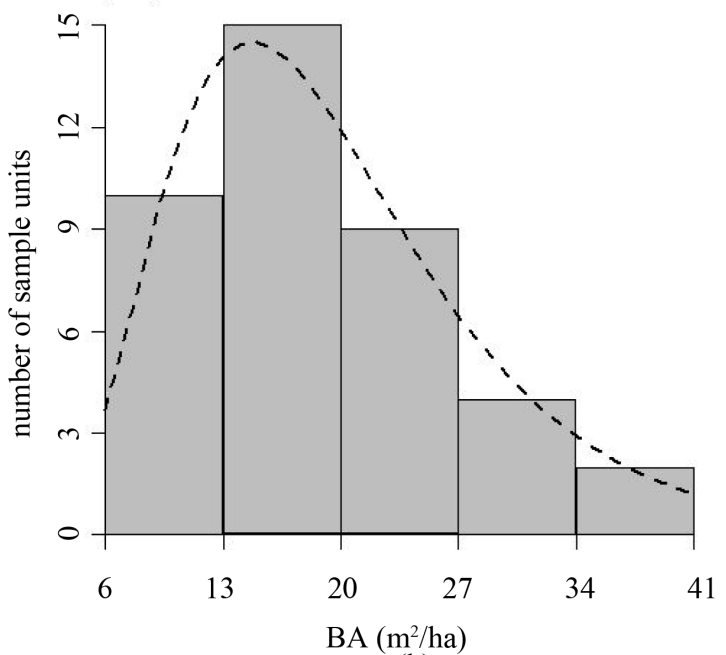

(b)

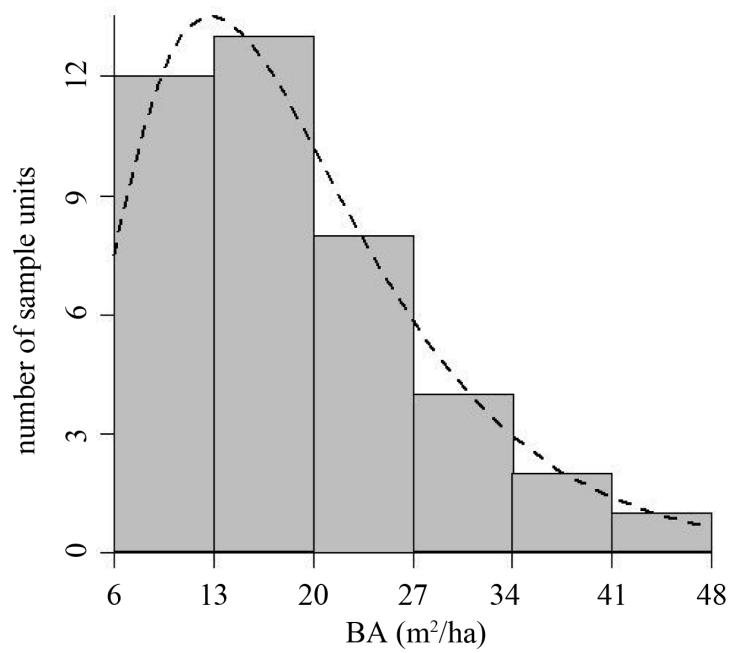

(c)

Figure 5. Distribution of basal area (m²/ha): (a). 2006; (b). 2010; (c). 2014. 


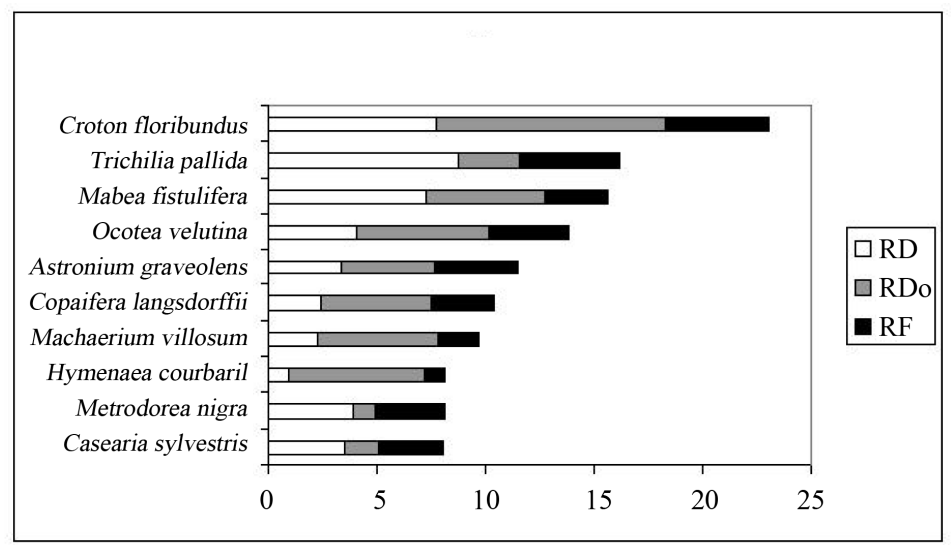

(a)

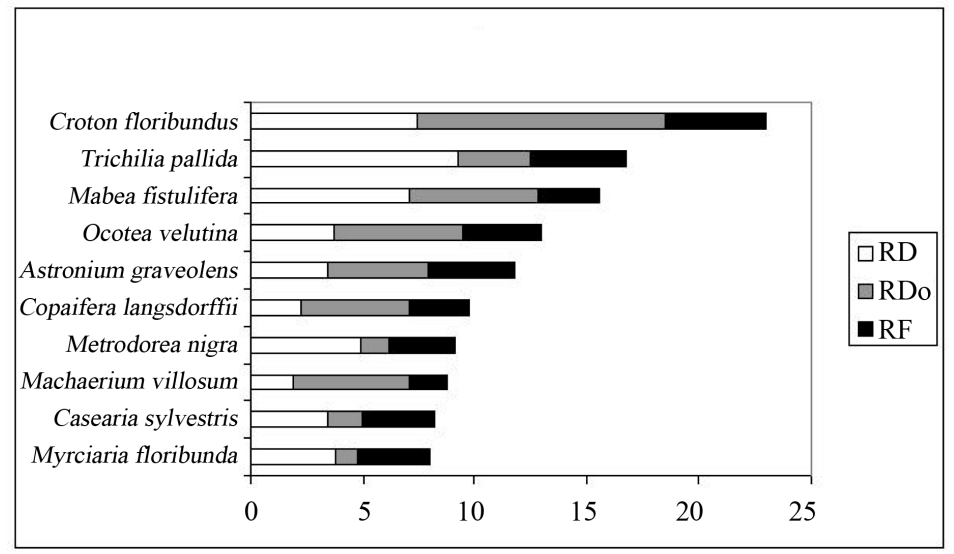

(b)

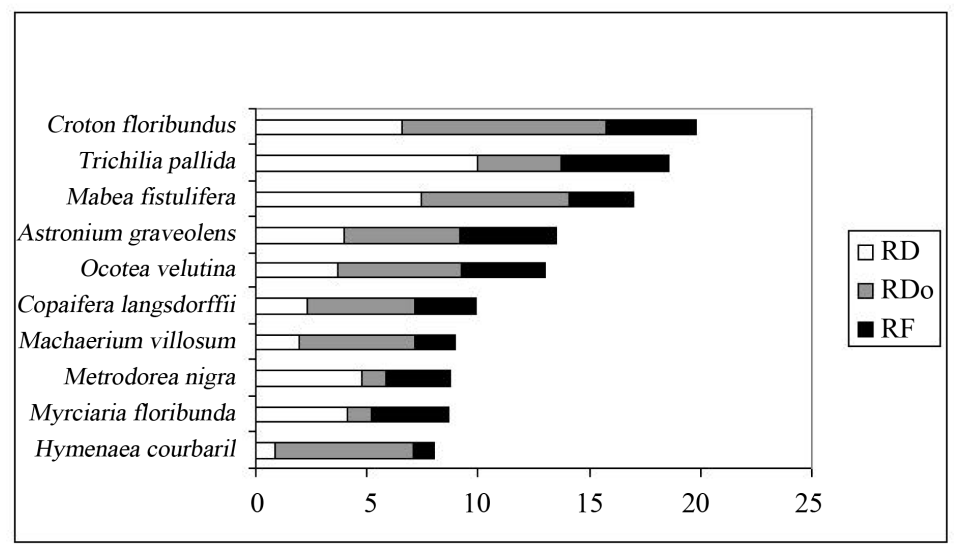

(c)

Figure 6. Ten species with the highest importance index values: (a) 2006; (b) 2010; (c) 2014 .

was kept within the confidence limits, indicating random distribution pattern. The spatial distribution pattern for Ocotea velutina depended on the scale of analysis. Ocotea velutina has shown a pattern of aggregate distribution for a radius distance among individuals within 0 and 10 meters and randomized distribution for subjects with distance greater than 10 meters among them.

The dispersion of seeds produced by the parent plant is the initial process which generates the spatial distribution of a particular species. For a species for which the dispersion occurs by the wind (anemochory), a random distribution of individuals would be expected. Regarding autochory, the expectation lies in the deposition of 


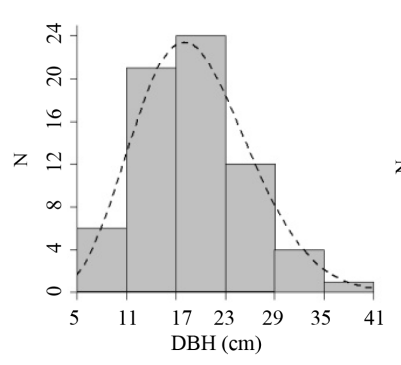

(a)

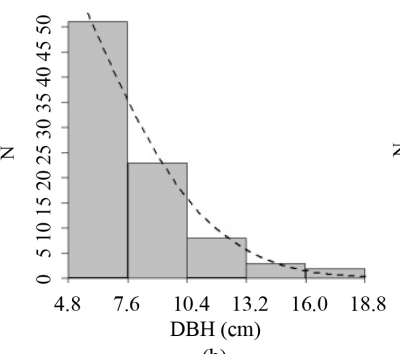

(b)

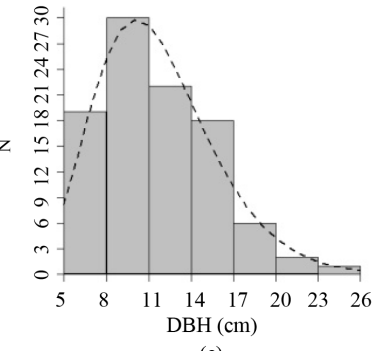

(c)

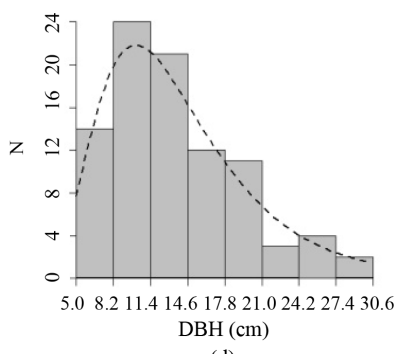

(d)

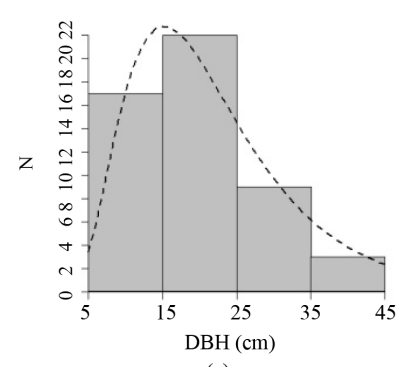

(e)

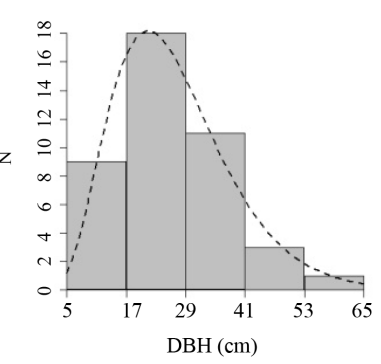

(f)

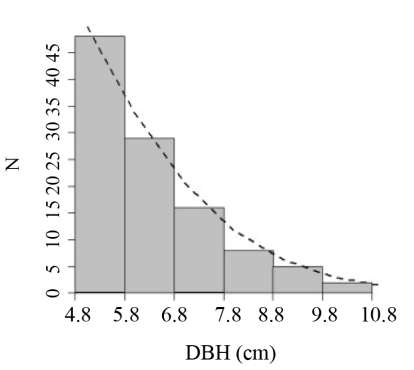

(g)

Figure 7. Diameter distribution of: (a) Croton floribundus; (b) Trichilia pallida; (c) Mabea fistulifera; (d) Ocotea velutina; (e) Astronium graveolens; (f) Copaifera langsdorffii; (g) Metrodorea nigra.

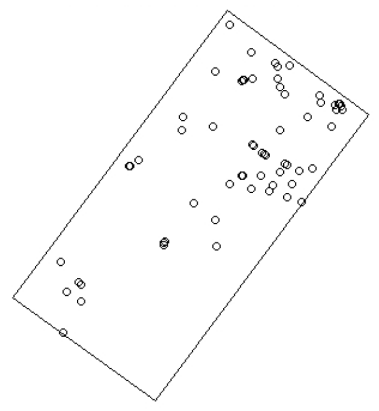

(a)

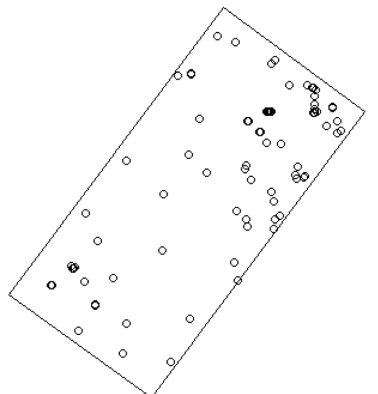

(b)

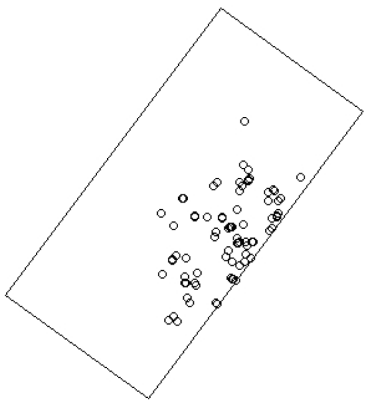

(c)

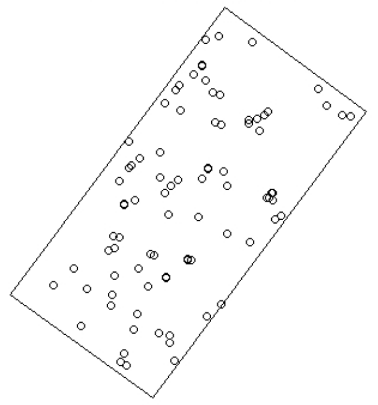

(d)

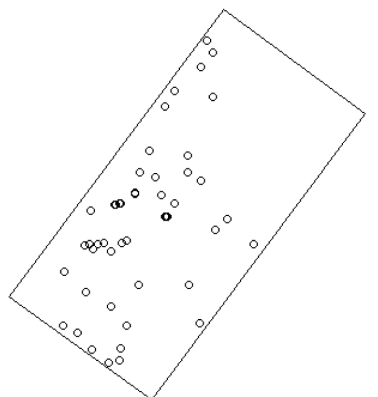

(e)

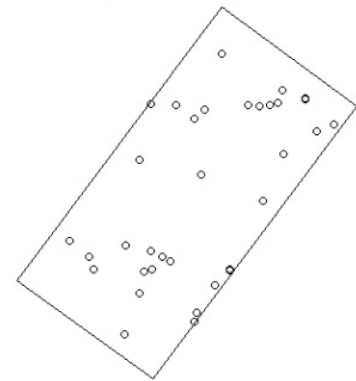

(f)

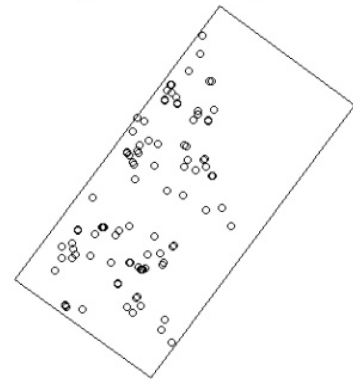

(g)

Figure 8. Spatial distribution of individuals: (a) Croton floribundus; (b) Trichilia pallida; (c) Mabea fistulifera; (d) Ocotea velutina; (e) Astronium graveolens; (f) Copaifera langsdorffii; (g) Metrodorea nigra.

seeds/fruit in certain micro sites, more specifically around the parent plant, setting an aggregated distribution. Such pattern would also be plausible for species dispersed by animals (zoochory), since there is often deposition of seeds in certain locations, such as feeding perches. Harms et al. (2000) and Jordano and Godoy (2002) observed dispersion by animals with seed accumulation at certain points, while much of the area was not affected by the spread, in contrast to the usual random patterns of anemochoric species. These likely direct associations 


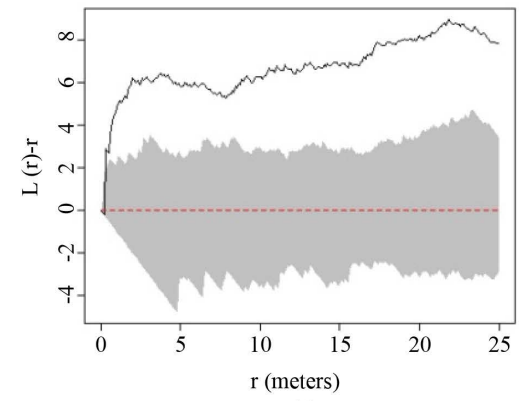

(a)

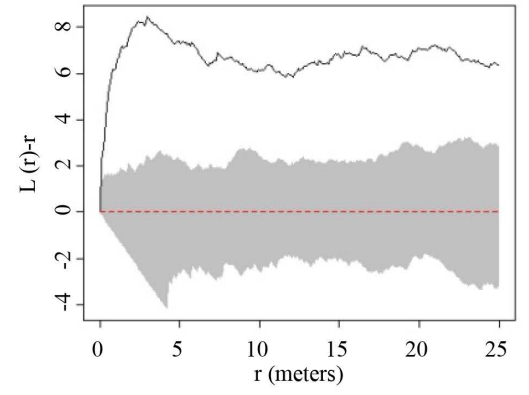

(b)

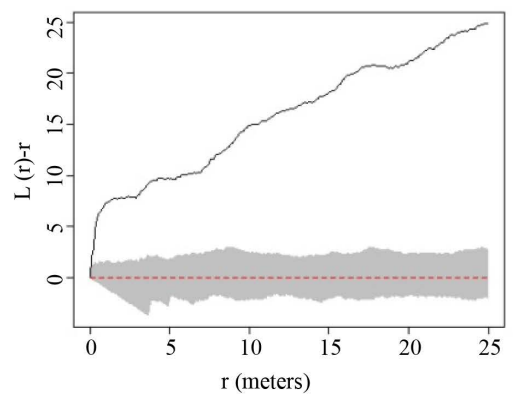

(c)

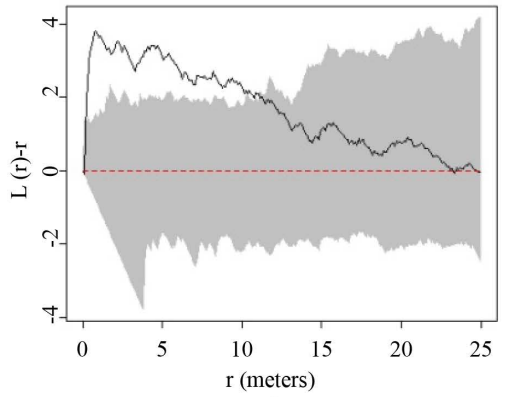

(d)

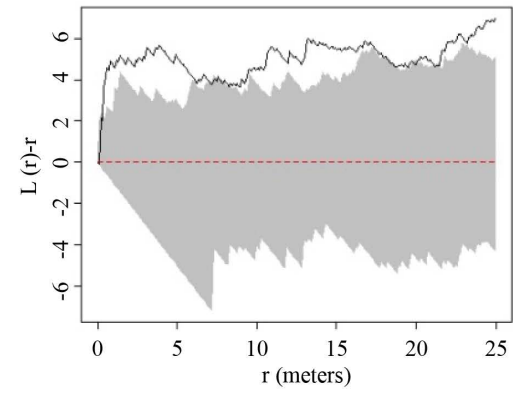

(e)

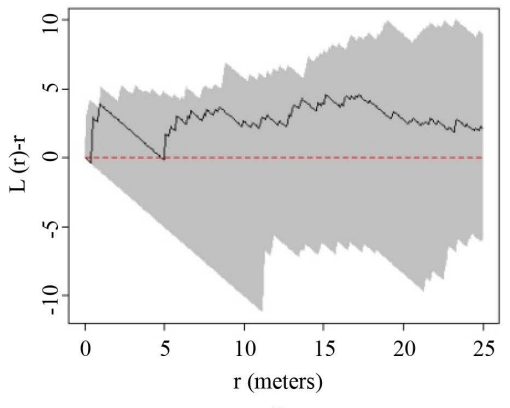

(f)

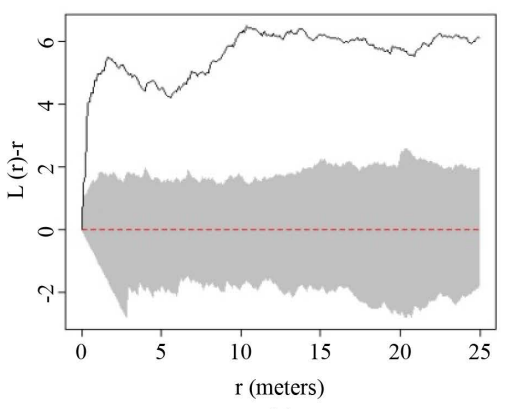

(g)

Figure 9. L-function and confidence envelope for: (a) Croton floribundus; (b) Trichilia pallida; (c) Mabea fistulifera; (d) Ocotea velutina; (e) Astronium graveolens; (f) Copaifera langsdorffii; (g) Metrodorea nigra.

Table 3. Statistics related to the equations adjusted for inverse-J-shaped diameter distribution.

\begin{tabular}{|c|c|c|c|c|c|c|}
\hline Distribution & Model & $a$ & $\boldsymbol{b}$ & S.E. & No. iterations & AI (\%) \\
\hline \multirow{3}{*}{ Trichilia pallida } & (8) & $260.239418^{* *}$ & $-0.27586^{* *}$ & 1.9990 & 6 & 99.21 \\
\hline & (9) & $88.440622^{* * *}$ & $-0.01583^{* * *}$ & 0.8968 & 4 & 99.84 \\
\hline & (10) & 2830.120475 & $-1.62969^{* *}$ & 2.8720 & 10 & 98.36 \\
\hline \multirow{3}{*}{ Metrodorea nigra } & (8) & 626.920492 & $-0.49463^{* *}$ & 3.7620 & 9 & 95.98 \\
\hline & (9) & $127.843453^{* *}$ & $-0.03717^{* *}$ & 2.8770 & 6 & 97.65 \\
\hline & (10) & 15947.741390 & $-2.54225^{* *}$ & 4.2850 & 15 & 94.79 \\
\hline
\end{tabular}

${ }^{* * *} \mathrm{P} \leq 0.001 ;{ }^{* *} \mathrm{P} \leq 0.01 ;{ }^{*} \mathrm{P} \leq 0.05$.

between the spatial distribution pattern found and the dispersion syndrome has not been observed for all of the seven most abundant species in the study area (Table 5). This indicates that in the process for Astronium graveolens and Copaifera langsdorffii, besides the seed dispersal, other aspects related to ecophysiological characteristics of species (phenology, intra and interspecific competition) have shown up, as well as environmental 
Table 4. Statistics related to the equations adjusted for unimodal diameter distribution.

\begin{tabular}{|c|c|c|c|c|c|c|c|c|}
\hline Distribution & Model & $b_{0}$ & $b_{1}$ & $b_{2}$ & $\gamma$ & S.E. & $R_{\text {adjusted }}^{2}$ & AI (\%) \\
\hline \multirow{3}{*}{ Croton floribundus } & (18) & $-9.55245^{* * *}$ & $7.06202^{* * *}$ & $-0.42328^{* * *}$ & 1 & 0.1014 & 0.9928 & 97.98 \\
\hline & (19) & $-4.62301^{* *}$ & $3.25689^{* * *}$ & $-0.00505^{* * *}$ & 2 & 0.0850 & 0.9949 & 99.50 \\
\hline & $(20)$ & $-8.13890^{* *}$ & $14.77750^{* *}$ & $-7.37980^{* *}$ & $1 / 2$ & 0.1827 & 0.9766 & 93.47 \\
\hline \multirow{3}{*}{ Mabea fistulifera } & (18) & $-5.16013^{*}$ & $6.52235^{* *}$ & $-0.64644^{* * *}$ & 1 & 0.1918 & 0.9786 & 96.73 \\
\hline & (19) & -0.89075 & $2.29086^{*}$ & $-0.01108^{* *}$ & 2 & 0.2359 & 0.9677 & 95.03 \\
\hline & (20) & -1.05920 & $15.02790^{* * *}$ & $-9.51500^{* * *}$ & $1 / 2$ & 0.1913 & 0.9787 & 96.04 \\
\hline \multirow{4}{*}{ Ocotea velutina } & (18) & -0.84583 & 2.94025 & $-0.29244^{*}$ & 1 & 0.3364 & 0.8695 & 91.20 \\
\hline & (19) & 1.64965 & 0.73802 & $-0.00427^{*}$ & 2 & 0.3754 & 0.8375 & 84.84 \\
\hline & (20) & 0.72890 & $7.36100^{*}$ & $-4.62700^{*}$ & $1 / 2$ & 0.3194 & 0.8824 & 93.66 \\
\hline & $(21)$ & $481.54000^{* *}$ & $50.62000^{* *}$ & $-489.24000^{* *}$ & 0.085 & 0.3077 & 0.8909 & 95.20 \\
\hline \multirow{4}{*}{ Astronium graveolens } & (18) & -1.52944 & 2.65426 & -0.17303 & 1 & 0.1465 & 0.9614 & 97.72 \\
\hline & (19) & 1.10459 & 0.84413 & -0.00180 & 2 & 0.2138 & 0.9177 & 94.63 \\
\hline & $(20)$ & -1.49870 & 6.37560 & -3.26850 & $1 / 2$ & 0.1130 & 0.9770 & 98.72 \\
\hline & (21) & $10.12200^{*}$ & 11.37610 & -16.77620 & 0.3 & 0.0999 & 0.9820 & 99.02 \\
\hline \multirow{3}{*}{ Copaifera langsdorffii } & (18) & $-5.28260^{*}$ & $3.96967^{*}$ & $-0.18584^{*}$ & 1 & 0.1736 & 0.9777 & 97.44 \\
\hline & (19) & -1.16236 & 1.49285 & $-0.00145^{*}$ & 2 & 0.2425 & 0.9564 & 97.25 \\
\hline & (20) & $-6.30100^{*}$ & $9.04300^{*}$ & $-3.98200^{* *}$ & $1 / 2$ & 0.1828 & 0.9752 & 94.46 \\
\hline
\end{tabular}

${ }^{* * *} \mathrm{P} \leq 0.001 ;{ }^{* *} \mathrm{P} \leq 0.01 ;{ }^{*} \mathrm{P} \leq 0.05$

Table 5. Characteristics of the most abundant species.

\begin{tabular}{|c|c|c|c|}
\hline Species & Occurrence & Dispersion & $\begin{array}{c}\text { Spatial } \\
\text { Distribution }\end{array}$ \\
\hline Astronium graveolens & interior of forest fragments. & Anemochory & aggregate \\
\hline Copaifera langsdorffii & semi-deciduous forest-forested savanna ecotone. & Zoochory & random \\
\hline Croton floribundus & secondary formations of semi-deciduous forest. & Autochory/Zoochory & aggregate \\
\hline Mabea fistulifera & secondary vegetation in sandy soils. & Autochory & aggregate \\
\hline Metrodorea nigra & understory of dense forest; moist and shady places. & Autochory & aggregate \\
\hline Ocotea velutina & dense semi-deciduous forest and secondary formations. & Zoochory & aggregate/random \\
\hline Trichilia pallida & understory, gaps and edge of forest fragments. & Zoochory & aggregate \\
\hline
\end{tabular}

conditions (light availability, humidity, nutrients in the soil) in micro sites, where the seeds of the trees were deposited. Direct association between the spatial distribution and dispersion syndrome have been observed to Croton floribundus, Mabea fistulifera, Metrodorea nigra, Trichilia pallida and Ocotea velutina, in that case in specific scales.

\subsection{Occurrence of Species that Reflect the Natural Regeneration Process}

In the natural regeneration process of the vegetation in the forest fragment studied, the occurrence of four species (among the seven most abundant) could be analyzed within the two environments evidenced in the aerial photography in 1962 (Figure 10). Croton floribundus is seen at site 1 but mainly at site 2, used as pasture in the past (grazing pasture). Mabea fistulifera trees are located almost exclusively at site 2, in clearer places. There is no spatial interaction between these both species in a scale of 0 to 15 meters (Figure 11(a)). The spatial distribution of Croton floribundus is independent related to the distribution of the other two species (Figure 11(b) 


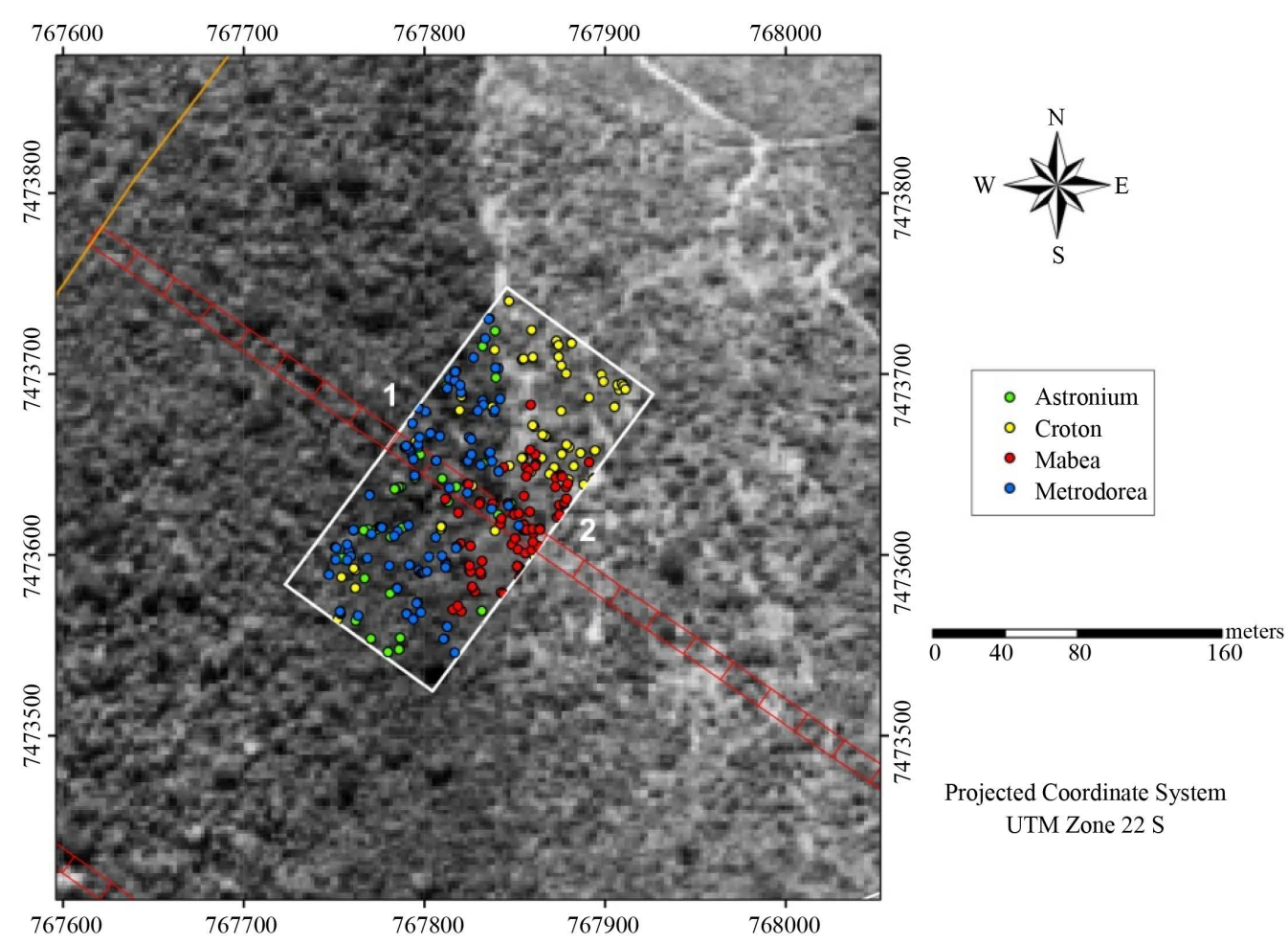

Figure 10. Occurrence of Astronium graveolens, Croton floribundus, Mabea fistulifera and Metrodorea nigra, in the sampled area of two hectares, on the aerial photography of 1962.

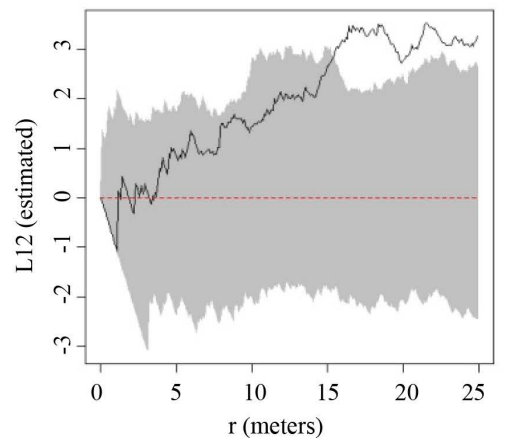

(a)

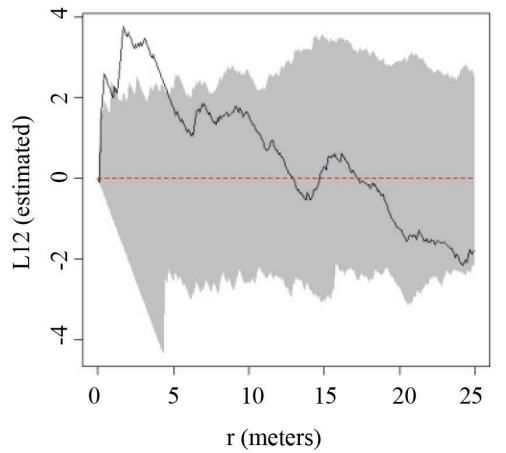

(d)

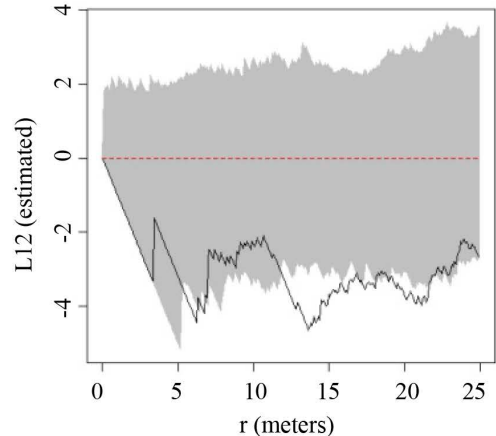

(b)

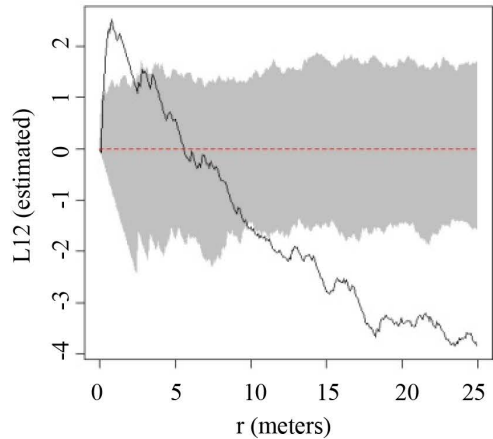

(e)

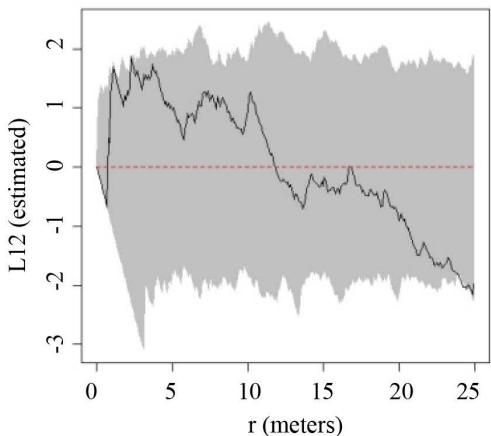

(c)

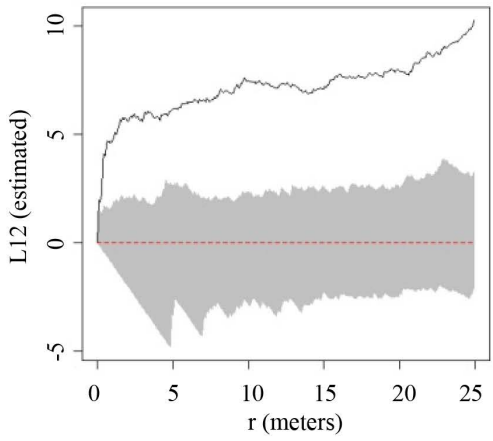

(f)

Figure 11. Spatial dependence analysis with the $\mathrm{K}_{12}$ function (estimated $\mathrm{L}_{12}$ ) for trees of: (a) Croton floribundus and Mabea fistulifera; (b) Croton floribundus and Astronium graveolens; (c) Croton floribundus and Metrodorea nigra; (d) Mabea fistulifera and Astronium graveolens; (e) Mabea fistulifera and Metrodorea nigra; (f) Astronium graveolens and Metrodorea nigra. 
and Figure 11(c)). The attraction among Mabea fistulifera and Astronium graveolens or Metrodorea nigra only occurs among individuals which are very close (Figure 11(d) and Figure 11(e)), showing a certain inhibition compared to Metrodorea nigra in the range from 10 to 25 meters. Astronium graveolens and Metrodorea nigra are regenerating mainly at site 1 , where there has been selective exploitation of tree species (last intervention from 1975 to 1980) but which, in a way, has kept its natural forest coverage. In the analysis of spatial dependence both species showed positive association/attraction (Figure 11(f)). Astronium graveolens occupies the upper canopy and Metrodorea nigra the understory in areas with denser forest coverage.

The spatial distributions of Astronium graveolens, Croton floribundus, Mabea fistulifera and Metrodorea nigra have provided signs of how the natural vegetation regeneration process is being processed before the two kinds of anthropogenic disturbances, common in tropical forest fragments areas.

An important aspect of researches conducted from surveys in forest fragments is related to the foundation they can offer in the selection of species to be used in areas with similar environmental conditions in restoration projects. An interesting method of ecological restoration is one based on framework species (Tucker and Murphy, 1997; Blakesley et al., 2002; Elliott et al., 2003). Framework tree species are indigenous forest tree species, planted to complement and accelerate natural regeneration of forest ecosystems and encourage biodiversity recovery, on degraded tropical sites. The method involves planting mixtures of $20-30$ species or roughly $10 \%$ of the estimated number of tree species in the target forest. In this context, as a development of this work, the pre-selection of the eleven species have been considered, the ones with the highest importance value (Figures 6(a)-(c)) related to the natural vegetation of the forest fragment studied, to be tested in restoration experiments using the framework species method.

\section{Conclusions}

The oscillation of the basal area, observed throughout the forest inventories carried out in 2006, 2010 and 2014, within the sampled area of one hectare consisting of contiguous permanent units, was due to the instability caused by the disturbances which happened in natural vegetation fragment under study.

Only two out of the seven most abundant species mapped in 2014 in the rectangular sampling unit with two hectares showed exponential diameter distribution (inverted J), indicating continuous regeneration, as would be expected for all of them. The unimodal distributions shown by the other five species indicated that the vegetation had been occupying the most open spaces, trying to colonize the areas which were most affected by the anthropogenic disturbances, by regeneration in cycles.

The exponential model of type II, adjusted for the two species that showed a diameter distribution pattern in inverted J, properly estimated the distributions and allowed checking that the decrease of individuals within the diameter classes took place in increasing geometrical progression.

Based on the classic exponential models, four models were developed for the five species that presented a unimodal diameter distribution pattern. Generally, the distributions were properly estimated by the equations, showing the potential use of the models.

Direct association has been verified between the spatial distribution and the dispersion syndrome for five out of the seven most abundant species. Three species are characterized by zoochorous dispersion, showing that wild animals' populations have accomplished their function as seeds/fruit dispersers.

The spatial distribution of four out of the seven most abundant species provided signs of how the regeneration of natural vegetation was being processed in this study area, before two kinds of characterized anthropogenic disturbances.

\section{References}

Baddeley, A. (2010). Analysing Spatial Point Patterns in R. Version 4.1. Perth: CSIRO and University of Western Australia. http://research.csiro.au/software/wp-content/uploads/sites/6/2015/02/Rspatialcourse_CMIS_PDF-Standard.pdf

Blakesley, D., Elliott, S. D., Kuarak, C., Navakitbumrung, P., Zangkum, S., \& Anusarnsunthorn, V. (2002). Propagating Framework Tree Species to Restore Seasonally Dry Tropical Forest: Implications of Seasonal Seed Dispersal and Dormancy. Forest Ecology and Management, 164, 31-38. http://dx.doi.org/10.1016/S0378-1127(01)00609-0

Carvalho, W. A., Panoso, L. A., \& Moraes, M. H. (1991). Levantamento semidetalhado dos solos da Fazenda Experimental Edgardia-Município de Botucatu. Botucatu: Faculdade de Ciências Agronômicas-UNESP, 467 p.

Cruz-Rot, M. (2006). Introdución al análisis de datos mapeados o algunas de las (muchas) cosas que puedo hacer si tengo 
coordenadas. Ecosistemas, 15, 19-39. http://www.revistaecosistemas.net/articulo.asp?Id=448

da Cunha, A. R., \& Martins, D. (2009). Classificação climática para os municipios de Botucatu e São Manuel, SP. Irriga, 14, 1-11. http://dx.doi.org/10.15809/irriga.2009v14n1p01 http://hdl.handle.net/11449/71044

Dalmaso, C. A., Inoue, M. T., Oliveira Filho, P. C., Marcelino, V. R., \& Pottker, G. S. (2012). Análise dos padrões espaciais de Ocotea odorifera (Vell.) Rohwer na Floresta Nacional de Irati (PR). Revista Ambiência, 8, 559-570. http://dx.doi.org/10.5777/ambiencia.2012.04.10 http://revistas.unicentro.br/index.php/ambiencia/article/view/1913/1773

Diggle, P. J. (2003). Statistical Analysis of Spatial Point Patterns. London: Academic Press.

Elliott, S. D., Navakitbumrung, P., Kuarak, C., Zangkum, S., Anusarnsunthorn, V., \& Blakesley, D. (2003). Selecting Framework Tree Species for Restoring Seasonally Dry Tropical Forests in Northern Thailand Based on Field Performance. Forest Ecology and Management, 184, 177-191. http://dx.doi.org/10.1016/S0378-1127(03)00211-1

Elliott, S.D., Blakesley, D., \& Hardwick, K. (2013). Restoring Tropical Forests: A Practical Guide. Kew: Royal Botanic Garden, 344 p.

Figueiredo, E. O., \& Cunha, R. M. (2007). Levantamento das árvores com coordenadas apropriadas com GPS de alta sensibilidade. In: E. O. Figueiredo, E. M. Braz, \& M. V. N. D’oliveira (Editores téCnicos), Manejo de precisão em florestas tropicais: modelo digital de exploração florestal (pp. 103-118). Rio Branco: Embrapa Acre.

Harms, K. E., Wright, S. J., Calderón, O., Hernández, A., \& Herre, E. A. (2000). Pervasive Density-Dependent Recruitment Enhances Seedling Diversity in a Tropical Forest. Nature, 404, 493-495. http://dx.doi.org/10.1038/35006630 http://www.stri.si.edu/sites/publications/PDFs/2000 NATURE.pdf

Hitimana, J., Kiyiapi, J., Njunge, J., \& Bargerei, R. (2009). Disturbance Indicators and Population Decline of Logged Species in Mt. Elgon Forest, Kenya. African Journal of Ecology, 48, 699-708. http://dx.doi.org/10.1111/j.1365-2028.2009.01167.x

Hughes, R. F., Kauffman, J. B., \& Jaramillo, V. J. (1999). Biomass, Carbon, and Nutrient Dynamics of Secondary Forests in a Humid Tropical Region of México. Ecology, 80, 1892-1907.

IBGE (2012). Manual técnico da vegetação brasileira (2 ed.). Rio de Janeiro: IBGE, Diretoria de Geociências, Departamento de Recursos Naturais e Estudos Ambientais, 271 p.

Jardim Botânico do Rio de Janeiro (2014). Lista de Espécies da Flora do Brasil. http://floradobrasil.jbri.gov.br/

Jordano, P., \& Godoy, J. A. (2002). Frugivore-Generated Seed Shadows: A Landscape View of Demographic and Genetic Effects. In D. J. Levey, W. R. Silva, \& M. Galleti (Eds.), Seed Dispersal and Frugivory: Ecology, Evolution and Conservation (pp. 305-321). New York: CABI Publishing.

http://www.researchgate.net/profile/Pedro_Jordano/publication//230807780_Frugivore-generated_seed_shadows_a_landsc ape_view_of_demographic_and_genetic_effects//links/0912f504df32a5b442000000.pdf

Loetsch, F., Zohrer, F., \& Haller, K. E. (1973). Forest Inventory (Vol. 2). München: BLV Verlagsgesellchaft, 469 p.

Müeller-Dombois, D., \& Ellemberg, H. (1974). Aims and Methods of Vegetation Ecology. New York: John Wiley \& Sons, $547 \mathrm{p}$.

R Core Team (2013). R: A Language and Environment for Statistical Computing. Vienna: R Foundation for Statistical Computing. http://www.R-project.org/

Ritz, C., \& Streibig, J. C. (2008). Nonlinear Regression with R. New York: Springer, 144 p.

Sagar, R., Raghubanshi, A. S., \& Singh, J. S. (2003). Tree Species Composition, Dispersion and Diversity along a Disturbance Gradient in a Dry Tropical Forest Region of India. Forest Ecology and Management, 186, 61-71. http://dx.doi.org/10.1016/S0378-1127(03)00235-4

Tucker, N. I. J., \& Murphy, T. M. (1997). The Effects of Ecological Rehabilitation on Vegetation Recruitment: Some Observations from the Wet Tropics of North Queensland. Forest Ecology and Management, 99, 133-152. http://dx.doi.org/10.1016/S0378-1127(97)00200-4

Wright, S. J. (2005). Tropical Forests in a Changing Environment. Trends in Ecology and Evolution, 20, 553-560. http://dx.doi.org/10.1016/j.tree.2005.07.009 